\title{
Genetic differentiation of Least Cisco (g. Coregonus) of Siberia reservoirs
}

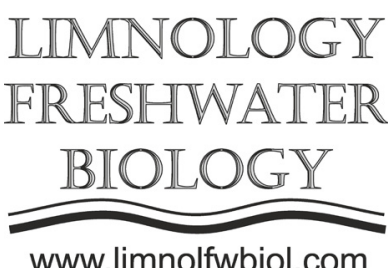

\author{
Nikulina Yu.S. ${ }^{1 *}$, Borovikova E.A. ${ }^{2}$ \\ ${ }^{1}$ National Research Tomsk State University, Lenina str., 36, Tomsk, 634050, Russia \\ ${ }^{2}$ Papanin Institute for Biology of Inland Waters, Russian Academy of Sciences, Borok, Yaroslavl Region, 152742, Russia
}

\begin{abstract}
The analysis of sequence polymorphism of the ND1 fragment of the mitochondrial DNA of least cisco (Coregonus sardinella) was performed. Two groups of haplotypes, or phylogenetic lineages, were revealed. The p-distance between these groups equals to $0.48 \%$ and does not exceed the intraspecific level. The currently observed pattern of genetic polymorphism in least cisco populations is largely related to the peculiarities of the distribution of the species from east to west during glaciations.
\end{abstract}

Keywords: least cisco, genetic polymorphism, mitochondrial DNA, ND1 fragment.

\section{Introduction}

Least cisco (g. Coregonus) is significant component of Siberian ichthyofauna and important object of fishing. This group of coregonid fish is characterized by a high level of morphological and ecological polymorphism. There are many of ecological forms of least cisco, which inhabited Siberian water bodies. Thus, molecular genetic analysis of polymorphism of least cisco populations can be successful for study of the ground of theirs morpho-ecological heterogeneity (Sendek et al., 2013). However, the studies of the genetic polymorphism of this group are very fragmentary and touch on the allozyme polymorphism (Politov et al., 2000; 2004; Sendek et al., 2013) and polymorphism of several fragments of the mitochondrial DNA (mtDNA) for some populations (Borovikova et al., 2018; Nikulina, 2019). Therefore, study of genetic polymorphism of least cisco populations of the Siberian water bodies is an actual task.

\section{Material and methods}

We analyzed the nucleotide sequence polymorphism of the mtDNA region containing the whole sequence of the gene for subunit I of the NADH dehydrogenase complex (ND1 fragment, 1867 base pair). A total of 87 fish DNA samples of least cisco from 14 populations were examined. The study covered 10 Siberian rivers - Messoyakha (Taz Bay basin), Neitayakha (Gydan Bay basin), Yenisei, Pyasina, Khatanga, Anabar, Lena, Yana, Indigirka, and Kolyma; 3 lakes of the Putorana Plateau - Sobachye, Lama, Kutaramakan; and the Kureysky reservoir (Yenisei
River basin). In addition, we included into analysis 14 specimens of 'saurey' and 'zeld' from the Pechora River where according to Sendek (2002) there is the zone of hybridization of vendace (C. albula) and least cisco (C. sardinella). Morphological and allozyme analyzes revealed the 'saurey' is more closely related to the vendace while 'zeld' to the least cisco (Solovkina, 1974; Reshetnikov, 1980; Sendek, 1998). For comparison, we also investigated 4 individuals of peled (C. peled) of Lake Kutaramakan. This species is closest phylogenetically to vendace and least cisco. Values of p-distance were calculated to evaluate genetic divergences of haplotypes and their groups.

\section{Results and discussion}

Analysis of 105 sequences of the ND1 fragment of least cisco, 'saurey', 'zeld', and peled revealed 84 haplotypes. The genetic divergence of ND1 haplotypes varied in a rather wide range: from 0.05 to $0.92 \%$, the average value was $0.42 \%$. These data could be evidence for a complex history of the origin of populations under consideration.

Eleven haplotypes of the ND1 fragment were found at more than one specimen. The other 73 haplotypes were revealed singly, i.e. were unique for particular population or region. The most frequent is N1 haplotype: five individuals from $87(4.8 \%)$ were carriers of this variant. However, this haplotype has rather limited distribution area and it is typical for least cisco of the Putorana Plateau lakes. The haplotype $\mathrm{N} 2$ was revealed for $3.8 \%$ individuals, including representatives of the 'zeld' as well as specimens from the Khatanga and Yana rivers. So, geographical 
distribution of this variant is wider than N1 despite the lower frequency. The largest number unique haplotypes (15) were found in the least cisco of the Yenisei River. However, perhaps this is because the sample is the most numerous of our analyzed (17 individuals). Only one unique haplotype was detected in the sample from Lake Kutaramakan (four individuals).

Analysis of the ND1 haplotype network revealed two clearly distinguished groups, or phylogenetic lineages. For least cisco of the Khatanga, Anabar, Lena, Yana, Indigirka, and Kolyma rivers the first group haplotypes were only typical ( $p$-distance within this group $=0.30 \%$ ). Individuals from the Kureysky reservoir and lakes of the Putorana Plateau (Sobachye, Lama, Kutaramakan) were carriers of only the variants of the second group ( $p$-distance $=0.34 \%$ ). At the same time, in samples of 'saurey' and 'zeld' of the Pechora River as well as Messoyakha, Naytayakha, Yenisei, and Pyasina rivers representatives both the first and second haplogroups were identified. These data supported the complex origin of populations of these water bodies and multiple migration in them of representatives of distinct phylogenetic lineages at different historical eras. It should be noted the differentiation between these lineages is small and does not exceed the intraspecific level $(p$-distance $=0.48 \%)$.

\section{Conclusions}

Thus, despite the wide variability of morphological features of the least cisco, genetic differentiation between ND1 haplotypes within and between populations is low: the p-distance values do not exceed the intraspecific level. The currently observed pattern of genetic polymorphism in least cisco populations is largely related to the peculiarities of the distribution of the species from east to west before the last glaciation.

\section{Acknowledgements}

We are grateful to Romanov V.I., Zadelenov V.A., Budin Yu.V., Borovskoy A.V., and Burmistrov E. for the invaluable help in collecting the material. The study was supported by the Ministry of Education and Science Russia, the state assignment no. 0721-2020-0019.

\section{References}

Borovikova E.A., Romanov V.I., Nikulina J.S. 2018. Morphological and genetic features of cisco (Coregonidae: Coregonus sp.) from Lake Sobachye (Putorana Plateau). Russian Journal of Genetics: Applied Research 8: 37-43. DOI: 10.1134/S2079059718010033

Nikulina Yu.S. 2019. Phylogeography of least cisco of the Arctic Ocean basin. In: 7th Scientific and practical Conference on Modern problems and prospects for the development of the fish complex, pp. 356-360. (in Russian)

Politov D.V., Gordon, N.Y., Afanasiev et al. 2000. Identification of Palearctic coregonid fish species using mtDNA and allozyme genetic markers. Journal of Fish Biology 57: 51-71. DOI: 10.1111/j.1095-8649.2000.tb02244.x

Politov D.V., Bickham J.W., Patton J.C. 2004. Molecular phylogeography of Palearctic and Nearctic ciscoes. Annales Zoologici Fennici 41: 13-23.

Reshetnikov Yu.S. 1980. Ekologiya i sistematika sigovykh ryb [Ecology and systematics of Coregonids]. Nauka: Moscow. (in Russian)

Sendek D.S. 1998. About species affiliation of cisco inhabited the Pechora River. Sbornik Nauchnykh Trudov Gosudarstvennogo Nauchno-Issledovatel'skogo Instituta Ozernogo i Rechnogo Rybnogo Khozyaystva [Proceedings of GosNIORKH] 323: 191-198. (in Russian)

Sendek D.S. 2002. Electrophoretic studies of Coregonid fishes from across Russia. Archiv für Hydrobiologie [Fundamental and Applied Limnology] 57: 35-55.

Sendek D.S., Ivanov E.V., Fedorova E.A. 2013. Genetic differentiation of least cisco from four large rivers of Yakutia. Mezhdunarodnyy Zhurnal Prikladnykh i Fundamental'nykh Issledovaniy [International Journal of Applied and Fundamental Research] 8: 165-168. (in Russian)

Solovkina L.N. 1974. Vendace Coregonus albula sardinella (Val.) of the Pechora River basin. Voprosy Ikhtiologii [Ichthyology Issues] 14: 769-781. (in Russian) 